\title{
MOTIVASI BELAJAR SISWA MIS I'ANATUSHIBYAN 02 PARUNG
}

\author{
Nurlailah $^{1}$, Rika Oktapiani ${ }^{2}, \mathrm{Ika}^{3}$ \\ ${ }^{1}$ MIS I'anatusshibyan \\ Email: bundaazkaa1@gmail.com. \\ ${ }^{2}$ MIS I'anatusshibyan \\ E-mail: oktavianirieka@gmail.com. \\ ${ }^{3}$ STAI Fatahillah Tangerang \\ E-mail: ikaclar@gmail.com.
}

\begin{abstract}
Besides that, school is also a product where humans are educated and nurtured to become smart, productive, and qualifield human beings. The main purpose of education is to help students develop every potential that exsists in them so that they can become human beings who are balanced between their personal and social lives. The quality of student education outcomes can be determined by many factors, one of the most important is student motivation. Student motivation to learn greatly determines the success achieved by these student. Student who have high learning motivation will be able to achieve high learning achievement as well, but conversely, stuydent who have low motivation tend to get low learning achievement as well and will experience higher learning disabilities. To help increase a student's motivation to learn, it is necessary to know the level of student motivation to learn. The phenomenon in the field shows that the level of student learning motivation is very important to know so that it can help these student to improve it, this is known after the researcher conducted interviews with supervisors at the school, according to the supervisor some students in the school had low motivation. To actively participate in teaching and learning activities in the classroom. Student motivation in this study is related to motivation, driving, change, and goals of motivation it self. The school that was taken as the research location was MI I'anatusshibyan 02 Parung. The students referred to in this study were all students of MI I'anatusshibyan 02 Parung.
\end{abstract}

Keywords: Motivation; Learn; Analisys of CIPP model (Contex, Input, Process, Produck)

Abstrak: Sekolah menjadi suatu lembaga pendidikan yang menjadi wadah bagi para siswa untuk melakuakan berbagai kegiatan dan aktifitas belajar. Disamping itu, sekolah juga merupakan suatu produk dimana manusia dididik dan dibina menjadi manusia yang pandai, produktif dan berkualitas. Tujuan utama dari pendidikan adalah memebantu agar siswa dapat mengembangkan setiap potensi yang ada pada dirinya agar dapat menjadi manusia yang seimbang antara kehidupan pribadinya dan sosialnya. Kualitas hasil pendidikan siswa dapat ditentukan oleh banyak faktor, salah satu yang terpenting adalah motivasi belajar siswa.Motivasi belajar siswa sangat menentukan keberhasilan yang dicapai oleh siswa tersebut. Siswa yang memiliki motivasi belajar tinggi akan mampu meraih prestasi belajar yang tinggi pula, tetapi sebaliknya, siswa yang memiliki motivasi rendah cenderung mendapatkan prestasi belajar yang rendah pula dan akan mengalami kesuliatan belajar yang lebih tinggi. Untuk membantu meningkatkan motivasi belajar seorang siswa, perlu diketahui tingkat motivasi belajar siswa tesebut. Fenomena di lapangan menunjukkan bahwa tingkat motivasi belajar siswa sangat penting untuk diketahui agar dapat membantu siswa tersebut untuk meningkatkannya, hal ini diketahui setelah peneliti melakukan wawancara dengan guru pembimbing yang ada di sekolah tersebut, menurut guru pembimbing tersebut sebagian siswa di sekolah tersebut mempunyai motivasi yang rendah untuk berpartisipasi aktif dalam kegiatan belajar mengajar di kelas. Motivasi siswa dalam penelitian ini berkaitan 
Jurnal Konseling Pendidikan Islam

http://ejournal.alkhairat.ac.id/index.php/JKPI

ISSN: 2655-9692

EISN: 2746-5977

Jurnal Konseling Penclidikan Islam

Vol. 2 No. 2, Juli 2021

dengan dorongan, penggerak, perubahan dan tujuan dari motivasi itu sendiri. Sekolah yang diambil menjadi lokasi penelitianadalah MI I'anatusshibyan 02 Parung. Siswa yang dimaksud dalam penelitian ini adalah seluruh siswa MI I'anatusshibyan 02 Parung.

Kata kunci: Motivasi; belajar; analisis model CIPP (Contex, Input, Proses, Produck) 


\section{PENDAHULUAN}

Ajaran Islam telah menempatkan pendidikan pada kedudukan yang sangat penting karena manusia sebagai hamba Allah SWT di muka bumi memikul tugas dan tanggung jawab yang cukup berat. Agar manusia mampu menjalankan tanggung jawabnya dengan baik diperlukan ilmu pengetahuan yang sesuai dengan kehendak Allah. Hal itu hanya dapat dipenuhi dengan proses pedidikan. Pendidikan dalam Islam sangat penting, oleh karena itu, perintah pertama yang diberikan kepada hamba-Nya adalah "baca" yang terdapat pada wahyu pertama yang diturunkan kepada nabi Muhammad SAW yaitu surat Al-Alaq:15. Oleh sebab itu, motivasi belajar sangatlah penting agar manusia terus terdorong untuk selalu belajar, kapan pun dan dimana pun.

Menuntut ilmu merupakan sarana untuk menunaikan apa yang Allah wajibkan kepada kita. Tak sempurna keimanan dan amal kita kecuali dengan ilmu. Dengan ilmu, Allah disembah dan hak Allah ditunaikan dan dengan ilmu pula agama-Nya disebarkan. Hal ini membuat kebutuhan pada ilmu lebih besar dibandingkan dari kebutuhan yang lain, sebab keberlangsungan agama dan dunia bergantung pada ilmu.

Islam sangat memperhatikan pentingnya ilmu pengetahuan dan teknologi dalam kehidupan umat manusia. Di samping martabat manusia ditentukan oleh kemampuannya mengembangkan ilmu pengetahuan dan teknologi. Allah SWT sendiri dalam AlQur'an menyatakan bahwa hanya orang yang berilmulah yang benar-benar takut kepada Allah dan juga akan ditinggikan derajatnya (Rusyja Rustam: 2018). Selain ditinggikannya derajat bagi siapa saja yang berilmu, Allah SWT pun akan memudahkan jalan menuju syurga untuk hambanya yang senantiasa mencari ilmu.

Menuntut ilmu adalah salah satu jalan yang meyebabkan seseorang masuk syurga, karena dengan ilmu dia mengetahui batasan-batasan tata kehidupan, baik dengan alam, binatang maupun sesama manusia. Melalui ilmu agama Islam manusia akan dapat mendeferensiasi halal dan haram, sehingga menjauhi yang haram. Dan dengan ilmu dia mengetahui amalanamalan yang mengantarkannya menuju syurga sehingga dia mengikutinya. Dalam hadits tersebut terdapat keutamaan menuntut ilmu dan dapat memotivasi para siswa untuk selalu giat belajar tentunya dengan diniatkan ikhlas karena Allah SWT.

Keberhasilan anak dalam menuntutu ilmu pengetahuan merupakan dambaan setiap orang tua, tidak terkecuali juga bagi murid-murid Madrasah Ibtidaiyah I'anatusshibyan 02. Keberhasilan Pendidikan akan berdampak terhadap peningkatan cara berfikir yang akan membawa kearah kemajuan ekonomi. Pendidikan memiliki peran penting dalam kehidupan berbangsa dan bernegara dalam upaya menciptakan sumber daya manusia yang berkualitas. Pendidikan menjadi faktor kebutuhan dasar, karena melalui pendidikan upaya peningkatan kesejahteraan rakyat dapat diwujudkan. Perlu diingat bahwa faktor utama yang mendukung majunya suatu bangsa adalah sumber daya manusia yang produktif. Untuk menciptakan SDM yang produktif tentu hanya bisa dilakukan melalui Pendidikan yang berkualitas.

Kualitas hasil Pendidikan siswa dapat ditentukan oleh banyak faktor, salah satu yang terpenting adalah motivasi belajar siswa. Motivasi belajar siswa sangat menentukan keberhasilan yang dicapai oleh siswa tersebut. Siswa 
yang memiliki motivasi belajar tinggi, akan mampu meraih prestasi belajar yang tinggi, tetapi sebaliknya, siswa yang memiliki motivasi belajarnya rendah cenderung mendapat prestasi belajar yang rendah pula dan akan mengalami kesulitan belajar yang lebih tinggi.

Dalam motivasi belajar terkandung adanya cita-cita atau aspirasi siswa, ini diharapkan siswa mendapat motivasi belajar sehingga mengerti dengan apa yang menjadi tujuan dalam belajar. Disamping itu, keadaan siswa yang baik dalam belajar akan menyebabkan siswa tersebut bersemangat dalam belajar dan mampu menyelesaikan tugas dengan baik, kebalikan dengan siswa yang sedang sakit, ia tidak mepunyai gairah dalam belajar.

Motivasi berhubungan erat dengan kebutuhan dalam belajar. Kebutuhan yang tak bisa dihindari oleh siswa adalah keinginan untuk mengetahui sejumlah ilmu pengetahuan. Oleh karena itu mereka membutuhkan motivasi dalam belajar. Dalam kehidupan sehari-hari siswa membutuhkan penghargaan, siswa akan merasa berguna bila dikagumi dan dihormati oleh guru atau orang lain. Perhatian merupakan kebutuhan yang wajar bagi siswa. Karena ini dapat membrikan motivasi bagi siswa dalam belajar.

Secara Bahasa, "motivasi berasal dari Bahasa Latin, yakni movor, yang berarti menggerakkan (to move)" (Andi Makkulawu Panyiwi Kessi: 2019). Dari pengertian Bahasa ini dapat dipahami bahwa menggerakkan yang dimaksud adalah hasrat individu untuk melakukan sesuatu yang timbul dari diri sendiri dan menggerakkan tingkah laku individu tersebut. Besar kecilnya motivasi akan menentukan cepat atau lambatnya suatu pekerjaan. Dengan adanya motivasi dalam diri seseorang, akan menggerakkan dirinya untuk melakukan sesuatu hal yang positif. Penggerak ini bisa datang dari mana saja, dari diri sendiri bahkan orang lain pun dapat menjadi penggerak atau memotivasi untuk diri individu.

Sedangkan menurut Kamus Besar Bahasa Indonesia, "motivasi adalah dorongan, semangat, stimulus dan rangsangan. Secara istilah, motivasi adalah suatu tenaga, dorongan alasan, kemauan dari dalam yang menyebabkan kita bertindak, dimana tindakan itu diarahkan kepada tujuan tertentu yang hendak dicapai" (Departemen Pendidikan Dan Kebudayaan: 2018). Rangsangan dalam motivasi adalah dorongan atau sesuatu yang mempengaruhi seseorang untuk melakukan sesuatu agar mencapai apa yang menjadi tujuannya.

Pengertian secara bahasa sebagaimana di atas perlu diperkuat dengan pandangan para ahli. Simamora, mengungkapkan bahwa "motivasi adalah sebuah fungsi dari pengharapan individu bahwa upaya tertentu akan menghasilkan tingkat kinerja yang pada gilirannya akan membuahkan imbalan atau hasil yang dikehendaki“ Dirgahayu Lantara, dkk: t.t).

Menurut Hamalik, "pengertian motivasi merupakan perubahan energi dalam diri atau pribadi seseorang yang ditandai dengan timbulnya perasaan dan reaksi untuk mencapai tujuan" (Rinjani Efendi, dkk: 2020).

Pada hakikatnya, motivasi merupakan suatu dorongan yang diciptakan guru dalam proses belajar mengajar. Dorongan itu terjadi karena kemampuan guru membuat situasi yang menjadikan para siswa belajar. Karena belajar merupakan kegiatan siswa dalam bentuk membaca, mengerjakan sesuatu ataupun mengamati sesuatu. Sementara keinginan yang datang 
secara internal merupakan hasrat yang timbul dari dalam diri sendiri atas kondisi belajar yang telah diciptakan guru. Sebab tanpa suasana yang dikondisikan rasanya tidak mungkin siswa mampu melakukan aktivitas belajar.

Pemikiran ini melihat motivasi pada tingkat fokusnya siswa dalam belajar. Mereka (para pelajar) memusatkan sebanyak mungkin energi fisik atau psikis terhadap kegiatan belajar tanpa mengenal perasaan bosan, apalagi menyerah. Memang tidak mudah untuk mewujudkannya, namun sekolah sebagai institusi pendidikan harus mampu. Peran guru dalam proses belajar mengajar sangat menentukan. Guru harus mampu mendesain pembelajaran yang membuat siswa menjadi berkegiatan, tidak hanya datang, duduk dan diam mendengar guru menjelaskan materi pelajaran. Tetapi guru harus sebagai pembimbing siswa dalam beraktifitas memahami, menyelesaikan materi pelajaran secara mandiri. Siswa secara individu harus membaca, mengamati langkah-langkah penyelesaian materi pelajaran. Kemudian mengerjakan sendiri walaupun salah, karena dari kesalahan itu akan didapatkan yang benar atas usaha sendiri.

Tokoh lain mendefinisikan Motivasi belajar sebagai "perubahan tenaga didalam diri seseorang yang ditandai dengan timbulnya perasaan dan reaksi untuk mencapai tujuan. Motivasi belajar merupakan kebutuhan untuk mengembangkan kemampuan diri secara optimal, sehingga mampu berbuat yang lebih baik, berprestasi dan kreatif" (Shilphy A: 2020).

Perubahan energi dalam diri seseorang itu berbentuk suatu aktivitas nyata berupa kegiatan fisik. Dalam kegiatan belajar gurulah yang menentukan tentang kegiatan apa yang akan dilakukan siswa. Jadi guru harus menguasai materi pelajaran dari setiap mata pelajaran. Guru harus memahami secara mendalam tentang karakteristik materi pelajaran. Sehingga tahapan belajar untuk mencapai tujuan pembelajaran dapat dilakukan secara berkesinambungan. Motivasi belajar itu akan tumbuh apabila satu tahapan penyelesaian materi pembelajaran berhasil dikerjakan dengan baik, maka siswa yang bersangkutan akan bergairah untuk belajar. Gairah ini terjadi karena dia sudah berhasil melewati tahap demi tahap pembelajaran.

Definisi di atas juga mengungkapkan bahwa motivasi belajar yang baik akan dapat memberi nilai terhadap perkembangan prestasi dan kreatif siswa. Pendapat ini juga didukung oleh Moekijat yang mengatakan bahwa: "Pengaruhpengaruh kemampuan dan motivasi terhadap hasil belajar tidak bersifat menambah, akan tetapi berifat saling melengkapi, baik itu berupa dorongan keingin tahuan yang munculnya dari dalam diri siswa ataupun dari luar menjadikan siswa lebih penasaran untuk mengetahuai sesuatu hal." (M Iqbal Harisuddin: 2019)

Karena motivasi dan hasil belajar saling melengkapi. Dapat digambarkan bahwa kemampuan intelegensi tinggi tidak menjamin seutuhnya siswa akan berprestasi tinggi. Siswa yang berintelegensi tinggi tanpa ada motivasi untuk belajar tidak menutup kemungkinan mereka mengalami kegagalan. Namun siswa yang kurang mampu secara intelegensi, tetapi berhasil memanfaatkan motivasi dalam belajar. Maka tingkat keberhasilan pendidikannya sangat bisa diharapkan. Ketekunan dalam belajar akibat dari motivasi dalam bentuk rasa ingin membahagiakan orang tua. 
Keberhasilan dari motivasi ini banyak kita lihat pada alam nyata.

Dalam hal ini individu harus memahami diri sendiri tentang sesuatu perbuatan. Jadi masing-masing individu harus mengerti untuk apa dia berbuat, dan mengapa dia berbuat demikian. Dari motif yang dipahami siswa masingmasing akan mengatur dirinya dalam suatu tindakan yang terencana dengan baik. Mungkin mereka akan membuat jadwal belajar, khususnya diluar jam sekolah. Mengatur jam kunjungan pustaka, mengidentifikasi buku-buku yang wajib dibaca, yang layak dibaca untuk dapat memahami materi pelajaran. Dan tidak menutup kemungkinan punya waktu khusus untuk belajar bersama tema-teman sebagai tindakan saling bantu yang mengacu kepada aplikasi domain afektif dalam pendidikan.

Menurut Djamarah, "motivasi belajar adalah dorongan internal dan eksternal dalam diri seseorang" (Endang Titik Lestari: 2020), dorongan internal adalah dimana apabila pelajar memiliki motivasi intrinsik yang tinggi, maka pelajar tersebut akan mengutamakan sekolah dibandingkan yang lain, karena bagi mereka belajar merupakan suatu cara untuk mendapatkan ilmu pengetahuan, sedangkan dorongan eksternal atau disebut ekstrinsik dimana pelajar memilik tujuan yang ingin dicapai dalam pembelajarannya, sehingga belajar merupakan bukan kegiatan sehari-hari, sehingga pelajar yang bermain game memiliki motivasi belajar ekstrinsik, dan pelajar yang tidak bemain game memiliki motivasi intrinsik. Istilah motivasi belajar memiliki arti yang sedikit berbeda. Ia menggambarkan bahwa motivasi belajar adalah kebermaknaan, nilai, dan keuntungan-keuntungan kegiatan belajar tersebut cukup menarik bagi siswa untuk melakukan kegiatan belajar.

Dalam uraian di atas, peranan motivasi belajar sangat penting dan menentukan keberhasilan anak dalam belajar, motivasi dapat membantu orang tua dalam menyampaikan program pengajaran untuk mencapai hasil yang optimal sesuai dengan garis-garis besar program pengajaran di sekolah.

Dalam kegiatan belajar berlangsung dan berhasilnya bukan hanya ditentukan oleh intelektual, tetapi juga faktor-faktor intelektual, termasuk salah satunya adalah motivasi belajar. Tingkah laku manusia dibangkitkan dan diarahkan oleh kebutuhan-kebutuhan tertentu, seperti kebutuhan fisiologis, rasa aman, rasa cinta, dan kebutuhan estetika. Kebutuhan inilah yang mampu memotivasi tingkah laku individu. Oleh karena itu, apa yang seseorang lihat sudah mempunyai hubungan dengan kepentingan pribadinya.

Setiap orang yang melakukan suatu perbuatan akan mengarah kepada suatu tujuan, semakin jelas suatu tujuan yang ingin dicapai orang akan semakin semangatdan termotivasi untuk melakukan sesuatu, semakin kuat motivasi seseorang, semakin tinggi tindakan atau usaha yang dilakukannya dan hasil yang diperoleh akan lebih baik.

Dari pendapat di atas, dapat dijelaskan bahwa motivasi adalah penggerak dari motif-motif itu sendiri merupakan keadaan siap. Motif tidak dapat diamati langsung tetapi dapat diinterprestasikan dalam tingkah lakunya, berupa rangsangan, dorongan, atau pembangkit tenaga munculnya suatu tingkah laku tertentu.

Berdasarkan beberapa teori yang telah dikemukan di atas, maka dapat ditarik suatu rumusan dalam bentuk sintesa tentang motivasi belajar. 
Motivasi belajar merupakan perubahan energi dalam diri atau pribadi seseorang yang ditandai dengan adanya dorongan untuk menggerakan individu bereaksi dalam upaya menuju harapan dan tujuan belajar yang ingin dicapai secara optimal.

Dengan demikian motivasi belajar mutlak diperlukan. Tanpa adanya motivasi, tujuan belajar tidak akan tercapai secara optimal, motivasi mempunyai peranan penting dalam kegiatan belajar anak, karena motivasi adalah tenaga penggerak aktifitas anak secara individual atau berkelompok, motivasi dapat juga dimisalkan sebagai motor/mesin dan kemudi pada mobil.

Jadi, motivasi merupakan keadaan seseorang yang terdorong untuk melakukan suatu aktivitas guna mencapai tujuan yang diharapkan. Sebagai mana diperkuat Handoko yang mengatakan bahwa "motivasi adalah keadaan pribadi seseorang yang mendorong keinginan individu untuk melakukan kegiatan tertentu guna mencapai tujuan" (Muhammad Nursan: 2019). Motivasi dirumuskan sebagai dorongan, baik itu dorongan dari luar ataupun dalam seseorang.

Motivasi dapat memupuk optimisme dalam belajar. Siswa yang memiliki motivasi dalam belajar selalu yakin dapat menyelesaikan setiap pekerjaan yang dilakukan. Dia yakin bahwa belajar bukan perbuatan yang sia-sia. Misalnya setiap ulangan yang diberikan oleh guru, selalu dihadapi dengan tenang dan percaya diri. Dapat difahami bahwa dengan adanya motivasi pada individu dapat meningkatkan rasa keyakinannya dalam melakukan aktivitas belajar.

Untuk membantu meningkatkan motivasi belajar seorang siswa perlu diketahui tingkat motivasi belajar siswa tersebut. Fenomena di lapangan menunjukan bahwa tingkat motivasi belajar siswa sangat penting untuk diketahui agar dapat membantu siswa tersebut untuk meningkatkannya, hal ini diketahui setelah peneliti melakukan wawancara dengan guru pembimbing yang ada di sekolah tersebut, menurut guru pembimbing tersebut, sebagian siswa di sekolah tersebut mempunyai motivasi yang rendah untuk berpartisipasi aktif dalam kegiatan belajar mengajar di kelas. Dalam hal ini, siswa MI I'anatusshibyan 02 Parung yang akan diamati tingkat motivasi belajarnya, dan untuk membantu meningkatkan motivasi belajar siswa tersebut. Berdasarkan problematika di atas maka penelitian ini bertujuan untuk mengetahui penerapan motivasi belajar siswa MI I'anatusshibyan 02 Parung, serta untuk mengetahui faktor pendukung dan faktor penghambatnya.

\section{METODE}

Penelitian yang dilakukan ini merupakan penelitian deskreptif. Secara pengertian Sugiyono mendefinisikan bahwa" penelitian deskriptif adalah penelitian yang dilakukan terhadap variable mandiri yaitu tanpa membuat perbandingan atau menghubungkan dengan variable yang lain" (Sugiyono: 2001). Variabel mandiri pada penelitian ini adalah motivasi belajar siswa MI I'anatusshibyan 02 Parung. Pada variable ini tidak ada unsur perbanding dan juga tidak mempunyai hubungan dengan variable lain.

Penelitian deskriptif dimaksudkan untuk mendeskripsikan secara sistematis dan akurat suatu situasi atau populasi tertentu yang bersifat factual. Penelitian deskriptif dapat pula diartikan sebagai penelitian yang dimaksudkan untuk memotret fenomena individual, situasi atau kelompok tertentu yang terjadi baru-baru ini (Sudarwan Danim: 2003). Dengan kata lain, penelitian deskriptif juga berarti 
penelitian yang dimaksudkan untuk menjelaskan fenomena atau karakteristik individual, situasi, atau kelompok tertentu secara akurat.

Jenis penelitian deskriptif merupakan penelitian terhadap suatu objek yang tujuannya untuk membuat deskripsi/gambaran secara sistematis, factual dan actual mengenai fakta-fakta, sifat-sifat, serta hubungan antara fenomena yang diselidiki. Menurut Witnet, "penelitian deskriptif adalah pencarian fakta dengan interpretasi yang tepat, penelitian ini meliputi pengumpulan data untuk pengujian hipotesis yang tujuannya untuk dasar pengambilan keputusan dan mengenali perilaku fakta yang ada saat ini." (Zohrahayty: 2019). Dari pengertian ini, penulis berpendapat jenis penelitian deskriptif ini adalah penelitian yang berusaha menggambarkan fenomena yang terjadi secara nyata, realistic, aktual, nyata dan pada saat ini, karena penelitian ini untuk membuat deskripsi, gambaran atau lukisan secara sistematis dan akurat mengenai fakta-fakta serta hubungan antar fenomena yang diselidiki.

Dari sudut temuan, hasil penelitian hanya menggambarkan fenomena-fenomena yang terjadi pada siswa MI I'anatusshibyan 02 Parung. Fenomena yang dideskripsikan pada penelitian ini tentu harus sesuai dengan masalah yang diangkat. Berdasarkan judul maka permasalah yang digambarkan adalah sebatas motivasi belajar siswa. Pada pengungkapan hasil penelitian, peneliti hanya menyajikan sesuai dengan data yang didapatkan tanpa dilakukan analisis yang mendalam.

Pendeskripsian data hanya sebatas apa yang terjadi dan dilakukan siswa MI I'anatusshibyan 02 Parung. Selanjutnya, data yang digambarkan tersebut merupakan data yang diperoleh dalam rentang waktu proses penelitian. Dan data itu merupakan data yang didapatkan dari subjek penelitian yang bersifat tunggal. Dengan demikian penelitian ini tidak memerlukan kelompok kontrol sebagai pembanding sebab yang dicari hanya satu fenomena yaitu motivasi belajar siswa.

Jadi jelas bahwa penelitian ini menggunakan pendeketan deskriptif, yaitu penelitian yang bertujuan untuk mengungkapkan atau menggambarkan tentang motivasi belajar siswa MI I'anatusshibyan 02 Parung.

Ada pun jenis pendekatan penelitian ini adalah deskriptif. Jenis penelitian deskriptif kualitatif yang digunakan pada penelitian ini dimaksudkan untuk memperoleh informasi mengenai motivasi belajar siswa MI I'anatusshibyan 02 Parung secara mendalam dan konprehensif. Selain itu, dengan pendekatan kualitatif diharapkan dapat diungkapkan situasi dan permasalah yang dihadapi.

Pendekatan penelitian dapat juga disebut sebagai metode. Maka penelitian ini menggunakan metode deskriptif. Menurut Nasir, " Metode deskriptif dapat diartikan sebagai prosedur pemecahan masalah yang diselidiki dengan menggambarkan keadaan subjek atau objek dalam penelitian dapat berupa orang, lembaga, masyarakat dan yang lainnya yang pada saat sekarang berdasarkan fakta-fakta yang tampak atau apa adanya" (Ajak Rukajat: 2018). Dari pemikiran ini dapat dipahami bahwa penelitian ini hanya menggambarkan keadaan subjek yaitu siswa di MI I'anatusshibyan 02 Parung.

Sementara yang berhubungan dengan data penelitian, peneliti menggunakan dua metode pengumpulan data yaitu metode observasi dan wawancara. Metode observasiSugiyono mengatakan bahwa "Teknik pengumpulan data dengan observasi 
digunakan bila, penelitian berkenaan dengan perilaku manusia, proses kerja, gejala-gejala alam dan bila responden yang diamati tidak terlalu besar" (Sugiyono: 2010)

Dari ungkapan di atas dapat dipahami bahwa metode obsevasi relevan digunakan pada penelitian ini karena inti persoalan yang diteliti tentang perilaku manusia yaitu siswa MI I'anatusshibyan 02 Parung. Kemudian penelitian ini juga mengamati proses kerja yaitu aktifitas belajar siswa, baik di dalam maupun di luar kelas. Terakhir jika ditinjau dari sudut sampel maka metode ini juga cocok karena sampel penelitian ini juga berada pada skala kecil.

Selanjutnya metode wawancara menurut (Sugiyono: 2010) mengungkapkan bawa metode wawancara digunakan apabila peneliti ingin mengetahui hal-hal dari responden yang lebih mendalam dan jumlah respondenya sedikit/kecil“. Metode wawancara memiliki makna lebih dan memiliki tujuan jelas dibanding dengan percakapan biasa. Proses wawancara tersebut yaitu terjadi karena adanya pewawancara dengan orang yang menjadi narasumber untuk memperoleh informasi tentang permasalahan yang dibahas. Metode wawancara ini sebagai metode atau Teknik pengumpulan data penelitian adalah proses untuk mendapatkan informasi yang digunakan untuk tujuan penelitian dan dilakukan dengan Tanya jawab antara pewawancara dengan responden atau narasumber dengan menggunakan suatu daftar yang dinamakan panduan wawancara.

Dari pandangan yang dikemukakan buku ini dapat dipahami bahwa metode wawancara juga masih cocok untuk penelitian ini karena memang peneliti ingin mengetahui halhal yang berhubungan dengan motivasi lebih mendalam. Dari sudut responden memang penelitian ini mengambil sampel yang sedikit yaitu siswa MI I'anatusshibyan 02 Parung. Sampel tersebut juga tidak diambil dari semua jenjang kelas.Pengumpulan data merupakan salah satu tahapan penting dalam penelitian. Data dikumpulkan dari sumbernya dengan cara wawancara. Yang dimaksud dengan sumber data dalam penelitian adalah suatu subyek dari mana data diperoleh. Namun untuk melengkapi data penelitian dibutuhkan dua sumber data, yaitu sumber data primer dan sumber data skunder. Data primer adalah data yang menjelaskan atau berkaitan langsung dengan objek penelitian, tentang peranan guru dalam mengendalikan siswa. Sedangkan data sekunder adalah yang tidak berkaitan secara langsung dengan objek penelitian, akan tetapi membantu menjelaskan objek penelitian.

Analisis data dalam penelitian kualitatif di mulai dengan menyiapkan dan mengorganisasikan data (yaitu data teks seperti transkrip atau data gambar seperti tokoh) untuk analisis kemudian mereduksi data tersebut menjadi melalui proses pengkodean dan peringkasan kode (Umrati, dkk: 2020) Penelitian ini lebih banyak bersifat uraian dari hasil wawan cara dan dokumentasi. Data yang telah diperoleh akan dianalisis secara kualitatif serta diuraikan dalam bentuk deskriptif.

Analisis data kualitatif dilakukan sejak sebelum memasuki lapangan, selama di lapangan, dan setelah selesai dilapangan. Analisis terjadi sejak merumuskan dan menjelaskan masalah. Miles \& Huberman mengemukakan bahwa" analisis data dilakukan secara interaktif dan berlangsung secara terus menerus sampai tuntas dan datanya penuh.Hamidah: 2020)"

Teknik analisis data yang digunakan dalam penelitian kualitatif 
mencakup transkip hasil wawancara, reduksi data, analisis data triangulasi (mengecek kebenaran). Berikut ini adalah Teknik analisis data yang digunakan oleh peneliti

\section{HASIL}

Dalam penelitian kualitatif analisis data merupakan tahap yang bermanfaat untuk menalaah dta yang telah diperoleh dari beberapa informan yang telah dipilih selama penelitian berlangsung. Selain itu juga berguna untuk menjelaskan dan memastikan kebenaran temuan penelitian. Analisis data ini telah dilakukan sejak awal dan berasamaan dengan proses pengumpulan data di lapangan.

Adapun dari penelitian yang telah dilakukan, peneliti mendapatkan beberapa temuan yang dapat menggambarkan motivasi belajar siswa yang terlihat dari observasi dan wawancara dimana motivasi siswa dalam belajar angatlah besar.

Secara teknis, untuk memotivasi siswa dalam belajar melibatkan orang lain ataupun orang tua sebagai motivator . Serta bentuk atau model motivasi belajar siswa yang dilakukan dalam suasana nyaman, santai dan rileks.

Merujuk pada hasil penyajian data yang peneliti sajikan pada sub-bab sebelumnya. Saat ini secara mendetail dan sistematis dapat peneliti sampaikan temuan-temuan apa saja yang diperoleh dari hasil penyajian data tersebut, dan fokus peneliti.
a. Motivasi belajar dalam bentuk dorongan
b. Motivasi belajar dalam bentuk penggerak
c. Motivasi belajar dalam bentuk perubahan
d. Motivasi belajar dalam bentuk harapan

\section{Hasil Wawancara \\ Dalam kegiatan penelitian,} wawancara adalah hal yang sangat penting guna menjawab segala pertanyaan peneliti. Wawancara dilakukan oleh peneliti kepada narasumber terpercaya untuk mendapatkan informasi yang tepat dan akurat. Menurut Sugiono“ wawancara merupakan pertemuan dua orang untuk bertukar informasi dan ide melalui Tanya jawab, sehingga dapat dikontruksikan makna dalam suatu topic tertentu (Ratna Ekasari: 2020). Wawancara juga merupakan alat mengecek ulang atau pembuktian terhadap informasi atau keterangan yang diperoleh sebelumnya dan juga merupakan teknik komunikasi langsung antara peneliti dan responden.

Untuk mengetahui cara memotivasi siswa, dapat dilakukan melalui wawancara terhadap guru setempat. Motivasi siswa dalam belajar di kelas sangat beragam. Hal ini dapat dilihat dari sikap atau pun respon siswa tersebut terhadap pelajaran. Kebanyakan dari siswa sangat semangat dalam mengikuti pelajaran akan tetapi ada juga sebagian siswa kurang antusias dalam mengikuti pelajaran, hal ini dikarenakan siswa memiliki latar belakang yang berbeda satu sama lain.

Dalam wawancara yang peneliti lakukan dengan narasumber yaitu guruguru MI I'anatusshibyan 02 Parung, mereka memiliki cara yang berbeda dalam menggerakkan minat belajar siswa, tentunya cara ini disesuaikan dengan tingkatan atau usia mereka. Menurut guru kelas I, sarana dan prasarana yang memadai dapat menggerakkan minat belajar siswa, mengingat bahwa anak-anak usia ini sangat cepat bosan bila kita melakukan kegiatan dengan monoton. Ketika mengguanak media atau alat peraga, 
fokus mereka akan pada benda yang dipegang oleh guru mereka.

Semua data hasil penelitian ini diuraikan berdasarkan fokus pertanyaan penelitian sebagai berikut:

a. Cara menggerakkan minat belajar siswa

b. Cara mendorong semangat belajar siswa

c. Perubahan perilaku belajar siswa setelah mendapatkan motivasi

d. Harapan dari hasil belajar Dengan demikian motivasi merupakan usaha-usaha yang dapat menyebabkan seseorang memiliki harapan dalam hidupnya untuk bergerk melakukan sesuatu keinginan mencapai tujuan yang dikehendakinya atau mendapat kepuasan dengan perbuatannya.

\section{PEMBAHASAN}

Setelah penulisan paparan data dan data temuan yang dihasilkan oleh peneliti dari wawancara dan observasi, maka selanjutnya peneliti akan menganalisi data yang telah terkumpul.

Dari paparan data dan hasil sub bab hasil temuan penelitian yang dijabarkan pada sub bab sebelumnya, maka perlu adanya analisi hasil penelitian. Hal ini dilakukan agar data yang dihasilkan tersebut dapat dilakukan interprestasi sehingga dapat mengambil kesimpulan penelitian sesuai dengan rumusan masalah yang diajukan. Dalam hal ini, Sugiono menyatakanm analisis telah dimulai sejak merumuskan dan menjelaskan masalah, sebelum terjun kelapangan, dan berlangsung terus sampai penulisan hasil penelitian. Namun dalam penelitian kualitatif, analisis data lebih difokuskan selama proses di lapangan bersama dengan pengumpulan data (Sugiyono: 2005).

$$
\begin{array}{rrr}
\multicolumn{2}{c}{\text { Penelitian disini }} & \text { menggunakan } \\
\text { analisis } & \text { deskriptif } & \text { kualitatif }
\end{array}
$$

(pemaparan) dari dua yang didapatkan baik melalui observasi dan wawancara dari pihak-pihak yang mengetahui tentang data yang dibutuhkan.

Dengan temuan bahwa tingkat motivasi siswa-siswi MI I'anatusshibyan 02 Parung tinggi, berarti hal ini telah sesuai dengan fenomena lapangan, para guru sangat mengharapkan siswasiswinya memiliki motivasi yang tinggi dalam belajar, berarti siswa memiliki pendorong sendiri yang cukup kuat, sehingga siswa memiliki motivasi yang kuat pula. Suatu motivasi akan kuat bila timbul dari dalam dirinya sendiri tanpa dorongan dari orang lain atau orang luar, motivasi tersebut merupakan keinginan dan kebutuhan siswa untuk datang ke sekolah, mengikuti pelajaran, mengerjakan tugas atau latihan, mengulangi pelajaran, dan membaca buku referensi tanpa dorongan dari luar atau orang lain.

Tingkat motivasi siswa MI I'anatusshibyan 02 Parung dalam bentuk dorongan dengan cara memberikan latihan kepada siswa, mengulang pelajaran dan mengerjakan pekerjaan rumah, berada ditingkat tinggi. Ini artinya, motivasi belajar siswa MI I'anatusshibyan 02 Parung terdorong atau termotivasi dalam hal mengerjakan tugas berada dalam tingkat tinggi, dan telah memenuhi harapan guru pembimbing namun tingkat tinggi tersebut perlu dipertahankan dan ditingkatkan lagi.

Berdasarkan pembahasan dan kesimpulan hasil penelitian dari penerapan metode pemberian tugas dapat meningkatkan dorongan motivasi belajar siswa MI I'anatusshibyan 02 Parung. Peneliti mengajukan beberpa saran agar siswa terus terdorong dalam mengikuti kegiatan pembelajaran, yaitu:

BKPI IAI Al-Khairat Pamekasan | 249 
a. Sebaiknya pelaksanaan metode pemberian tugas lebih sering diterapkan untuk meningkatkan motivasi belajar siswa.

b. Guru lebih dapat mengarahkan kegiatan belajar yang berpusat pada siswa, selalu membesarkan semangat belajar siswa, dan menghargai upaya atau hasil usaha belajar siswa.

Tingkat motivasi siswa MI I'anatusshibyan 02 Parung dalam bentuk perubahan, yang meliputi perubahan perilaku siswa dalam hal belajar berada ditinkat tinggi. Ini artinya, dorongan atau motivasi yang diberikan guru dapat diserap dengan baik oleh siswa dan siswa merubah dirinya menjadi lebih baik. Artinya, memotivasi siswa untuk berubah menjadi lebih baik berada ditingkat tinggi, dan telah memenuhi harapan guru pembimbing namun tingkat tinggi tersebut perlu dipertahankan dan ditingkatkan lagi.

Dengan deemikian, hakikat belajar adalah belajar yang selalu melibatkan tiga hal pokok, yaitu:

a. Adanya perubahan tingkah laku

b. Sifat perubahan relative permanen

c. Perubahan yang bersifat aktif

Seperti yang peneliti temukan dalam wawancara dan observasi dalam strategi peningkatan mutu pembelajaran yang peneliti lakukan di MI I'anatusshibyan 02 Parung. Menurut hasil dari observasi, menyatakan bahwa faktor yang berpengaruh terhadap pembelajaran ada dua, yaitu faktor internal (motivasi intrinsik) atau faktor yang timbul dari diri siswa, dan faktor eksternal motivasi ekstrinsik) yaitu faktor yang berasal dari lembaga sekolah sendiri. Membahas tentang faktor internal atau motivasi intrinsik, yaitu faktor yang timbul dari diri siswa secara individu, guru mengungkapkan bahwa siswa dalam kegiatan pembelajarannya selalu menunjukkan karakteristik mereka masing-masing. Yang berikutnya itu dapat dikatakan sebagai faktor yang mempengaruhi dalam kegiatan pembelajaran. Secara tidak langsung dari beragamnya karakteristik siswa, maka akan menimbulkan keaktifan atau bahkan gangguan dalam kegiatan pembelajaran.

Semua data diatas dihasilkan dari hasil observasi dan wawancara peniliti kepada para guru di MI I'anatusshibyan 02 Parung. Temuan tingginya tingkat motivasi menjadi tantangan bagi guru pembimbing untuk meningkatkan dan menjaga motivasi siswa tetap tinggi.

\section{SIMPULAN}

Setelah dilakukan penelitian sebagaimana yang telah dibahas pada bab sebelumnya, bahwa motivasi belajar siswa MI I'anatushibyan 02 Parung secara umum berada pada tingkat tinggi. Hal ini menunjukkan bahwa motivasi siswa MI I'anatusshibyan 02 Parung sudah tinggi dan diharapkan dapat lebih ditingkatkan lagi dimasa mendatang.

Motivasi merupakan suatu energi psikologis yang dimiliki oleh siswa atau peserta didik yang digunakan sebagai pendorong, penggerak dan pengarah perbuatan dalam suatu aktivitas pembelajaran yang menimbulkan perubahan tingkah laku sebagai hasil dari pengalaman atau latihan untuk mencapai tujuan pembelajaran. Berdasarkan hasil penelitian yang telah dilakukan diperoleh kesimpulan antara lain:

1. Motivasi belajar siswa MI I'anatusshibyan 02 Parung sebagai pendorong dengan cara memberikan latihan kepada siswa, seperti mengulang pelajaran dan mengerjakan pekerjaan dirumah, ternyata berada pada tingkat tinggi. Ini terbukti dari nilai hasil ulangan 
mereka yang memuaskan. Artinya, pemberian tugas untuk memotivasi belajar siswa sangat efektif untuk siswa MI I'anatusshibyan 02 Parung. Dan hal ini harus dipertahankan dan agar bisa lebih ditingkatkan lagi.

2. Tingkat motivasi siswa MI I'anatusshibyan 02 Parung dalam bentuk penggerak yang menggunakan metode pemberian reward perupa pujian dan hadiah ternyata berada pada tingkat sedang. Artinya reward dari guru kurang menarik minat siswa dan hampir memenhi harapan guru pembimbing dan penggerak motivasi harus ditingkatkan lagi.

3. Tingkat motivasi siswa MI I'anatusshibyan 02 Parung dalam bentuk perubahan, yang meliputi perubahan perilaku siswa dalam hal belajar berada ditinkat tinggi. Ini artinya, dorongan atau motivasi yang diberikan guru dapat diserap dengan baik oleh siswa dan siswa merubah dirinya menjadi lebih baik. Artinya, memotivasi siswa untuk berubah menjadi lebih baik berada ditingkat tinggi, dan telah memenuhi harapan guru pembimbing namun tingkat tinggi tersebut perlu dipertahankan dan ditingkatkan lagi.

\section{DAFTAR PUSTAKA}

Ajat Rukajat. 2018. Pendekatan Penelitian Kuantitatif, CV Budi Utama, Yogyakarta.

Albi Anggito \& Johan Setiawan. 2018. Metodologi Penelitian Kualitatif. CV Jejak, Sukabumi.

Andi Makkulawu Panyiwi Kessi. 2019.

Motivasi, Kompetensi, dan Penguasaan Teknologi

Informasi, Jagad Media

Publishing. Makasar.
Asep Hermawan. 2005.Penelitian Bisnis Paradigma Kuantitatif, Grasindo, Jakarta.

Bambang Waluyo.2020. Penelitian Hukum Dalam Praktek, Sinar Grafika, Jakarta.

Churin In Nabillah.2020. Tekun Berbahasa Indonesia, Farha Pustaka, Jawa Barat.

Departemen Pendidikan Dan Kebudayaan. 2018.Kamus Besar Bahasa Indonesia, Pusat. Balai Pustaka. Jakarta.

Dirgahayu Lantara dan Muhammad Nusran. 2018. Dunia Industri Perspektif Psikologi Tenaga Kerja, Makassar. Nas Media Pustaka. Makasar.

Endang Titik Lestari. 2020. Cara Praktis Meningkatkan Motivasi Siswa Sekolah Dasar. CV Budi Utama. Yogyakarta.

Fandi Ros. 2016. Teori Wawancara Psikodiagnostik. Yogyakarta.

Hamidah.2020. Kritik Atas Adopsi IFRS: Perspektif Ekolog Akuntansi. Peneleh. Malang.

Lina Asmara Wati. 2018. Ekonomi Produksi Perikanan Dan Kelautan Modern. UB Press. Malang.

Marsam. 2020. Pengaruh gaya Kepemimpinan, Kompetensi Dan Komitmen Terhadap Kinerja Pegawai. CV Qiara Media. Jawa Timur.

M. Iqbal Harisuddin. 2019. Secuil Esensi Berpikir Kreatif \& Motivasi Belajar Siswa. Panca Terra Firma. Bandung. Muhammad Nusran. 2019. Dunia Industri perspektif psikologi tenaga kerja. Media Pustaka. Makasar.

Ratna Ekasari. 2020. Model Efektivitas Dana Desa untuk Menilai Kinerja Desa Melalu 
iPemberdayaan Ekonomi, AE

Publishing. Malang

Rinja Efendi dan Delita Gustriani. 2020. Menejemen Kelas Di Sekolah Dasar. Penerbit Qiara Media. Pasuruan.

Rusyja Rustam \& Zainal Haris. 2018.

Pendidikan Agama Islam di Perguruan Tinggi. CV Budi utama. Sleman.

Shilphy A. 2020. Motivasi Belajar Dalam Perkembangan Remaja, Sleman. CV Budi Utama. Sleman.

Sudarwan Danim. 2003. Riset Keperawatan Sejarah \& Metodologi. Penerbit Buku Kedokteran EGC. Jakarta.

Sugiyono. 2001.Metode Penelitian Administrasi.Alfabeta, Bandung.

Sugiyono.2010. Metode Penelitian Kuantitatif Kualitatatif dan $R \&$ $D$. Alfabeta. Bandung.

Umrati,Hengki Wijaya. 2020. Analisi Data Kualitatif. Sekolah Tinggi

Theologia Press. Makasar

Zohrahayaty. 2019. Karakteristik PenelitianIlmu Komputer. CV Budi Utama. Yogyakarta. 